\title{
The Impact of Microfinance on Multidimensional Poverty Status of Rural Households in Gozamen District, East Gojjam Zone, Ethiopia
}

\author{
Yeshiwas Ewinetu Tegegne \\ College of Business and Economics, Debre Markos University,Department of Economics \\ Yirsie Alemayehu Geite* \\ College of Business and Economics, Debre Markos University, Department of Economics
}

\begin{abstract}
Microfinance aimed at breaking the vicious circle of poverty in Ethiopia by providing financial service and capacity building training for rural households. The main objective of this study is to examine the impact of microfinance service on mutidimestioanl poverty status of rural households. To attain this objective, the researchers collect primary data by using household survey from the total of 290 sample sizes 145 from treated group and 145 from non treated group respondents by using quasi experimental design. To analyze the data, the resrahcers employed descriptive statistics and inferential statics. The propensity score matching model result reveled that microfinance service has a negatively impact on the multidimensional poverty status of rural households. It is also found that microfinance service has reduced standard of living, health and educational dimensions of poverty for rural households of the study area respectively. It is recommended that the government should give special attention to support microfinance's institutions that support the rural poor household heads and improve the awareness level of farmers about its role towards poverty reduction.
\end{abstract}

Keywords:Microfinance, Multidimensional poverty, Impact assessment, Propensity score matching model, Gozamen district

DOI: $10.7176 / \mathrm{JESD} / 12-21-04$

Publication date: November $30^{\text {th }} 2021$

\section{Background of the study}

Poverty, with the problems that comes with it, is the major challenge of today's world. Though the level and dimension of poverty varies, there is no poverty free place in the world (Aziza, 2013). According to the United Nations report (2015), there are more than one billion people who are living below one dollar per day. And 2.7 billion people live on less than 2 dollar per day which is significant amount. However, poverty in the developing world goes beyond income poverty. People in the developing countries have to walk long distance to collect water and fire wood. More than six million children die from preventable disease like malaria, diarrhea and pneumonia. In some impoverished nations most children are not going to school. 114 million children do not get basic education and 584 million women are illiterate in the world. Over $40 \%$ of the world populations have not basic sanitation and four out of every ten people do not have access to latrine.

Ethiopia is one of the most multidimensional poorest countries in the world. According to the oxford poverty and human development initiative report on multidimensional poverty of developing countries, Ethiopia's multidimensional poverty level is calculated at 0.564 which is among the worst (Oxford Poverty and Human Development Initiative, 2014). Percentage of poor people which are below the cut-off $33.3 \%$ accounts for $87.3 \%$ and the average intensity of poverty across the poor stands for $64.6 \%$. In Ethiopia, multidimensional poverty is higher in rural areas than urban. This means the rural population is deprived in more indicators than the urban population. Multidimensional poverty varies among regions of Ethiopia. The lowest percentages of multidimensional poor people are found in Addis Ababa (0.085) and the highest (0.663) are found in Afar (OPHI, 2014). MOFED (2013) has reported that, the proportion of poor people accounts for about $29.6 \%$ at the national level using the $\mathrm{CBN}$ approach. The percentage of poor people in rural and urban Ethiopia is $30.4 \%$ and $25.7 \%$ respectively.

The nutritional poverty is also high in Ethiopia. Child nutrition is considered as a good proxy to measure nutritional poverty as they are the base of future poverty reduction effort. The percent of children under the age of five who are stunted and underweight is about $44 \%$ and $29 \%$ respectively. In both stunted and underweight of children boys outnumber girls. The stunted and underweight children are higher in rural Ethiopia (46.2\% \& $30.4 \%)$ and $31.5 \% \& 16.3 \%$ respectively in urban areas. There are regional disparities in stunted children: the highest being in Amhara region whiles the lowest in Addis Ababa (MOFED, 2013). According to MOFED report, on average, half of the population is illiterate at a national level. Urban literacy (78\%) is much higher than rural (40\%) literacy rate over ten-year-old children.

In Ethiopia around $90 \%$ of households have their own houses with the rural households' stands at $97.3 \%$ and 
urban $54.6 \%$. But most of their houses are constructed using wood and mud $(77.7 \%)$ and only $0.8 \%$ is constructed using stone and cement which shows low quality of houses. Wood is the most common cooking material (77.2\%) and electricity $1.2 \%$. Most households do not have standardized toilet and source of water. And only 40.8\%, $47.7 \%, 21.7 \%$ and $3 \%$ of the Ethiopian households have mobile, radio, TV and bicycle respectively (MOFED, 2013).

In Gozamen wereda, the proportion of population below poverty line is about $30.7 \%$. The poverty level is approximately similar to the national data. But there is slight decline in the poverty gap (Tsegaye, 2014).

Microfinance is the provision of financial services to the poor. Chiba (2009) has argued that sound institutions and evidence based policies are important, but they are not sufficient. In addition to the traditional approaches, a new and complementary approach is required to accelerate the millennium development goals, and microfinance can give such an alternative especially in developing countries. Access to microfinance is important to poor households in improving health condition; education and standard of living. The most important objective of microfinance is to reduce poverty with particular attention to the poorest sections of society given sustainability and outreach. It is believed that microfinance can help to reduce poverty by supplying credit with other services (Tenaw \& Islam, 2009). Microfinance has been generally considered as one of the most important instruments to reduce poverty by creating financial service access to the poor households and individuals. Degefe (2009) has pointed out that policy makers, donors and academics give emphasis to the role of microfinance as an important tool in reducing poverty and achieving economic growth. Microfinance has been well known in today's literature and international organizations. In the millennium development campaign microfinance has been one of the main targets. The benefits of microfinance services go beyond supporting business; it helps the poor to invest in education, health and meet household emergencies.

Microfinance has been one of the intervention mechanisms to reduce poverty in the Ethiopian government poverty reduction strategies like PASDEP and GTP. Microfinance services provide good support for national and regional poverty reduction by supplying financial services, mainly credit and saving. It is often noted that commercial banks are not accessible to the poor due to information problem, lack of collateral and impossibility of enforcement which contributes for financial market gap. This gap is expected to be filled by microfinance institutions (Mbithe, 2013). Access to microfinance services helps the poor in investing in new business and generates income, increasing their consumption and expenditure (Kasali, Ahmed and Ean, 2015). Microfinance institutions are expanding their services to the rural and urban areas; there by irreplaceable role to reduce poverty (Gosa, 2014).

Microfinance institutions are considered as deriving forces in job creation, saving mobilization and supplying credit in Gozamen wereda. Every government related action like supply of fertilizer; seeds and improved technology are carried out through microfinance institutions when credit is required. Currently there are two registered microfinance institutions in Gozamen wereda: Amhara credit and saving institution and specialized credit and saving institution; the lion share being ACSI. Around 8,250 households are users of micro finance services in 2015/16 which is about $27.4 \%$ of the total households. Though such amounts of households are being involved, its role on multidimensional poverty is not well known and lacks empirical evidence. This study is conducted with this regard.

Multidimensional poverty is a consistent problem facing a significant amount of rural and urban population in Ethiopia (Tsegaye, 2014 and Esubalew, 2006). Ethiopia's multidimensional poverty index was among the highest which makes $173^{\text {rd }}$ out of 187 countries (OPHI, 2014). Many of the rural areas in Ethiopia stood behind the developed countries due to lack of infrastructure, access to quality education, health services and living standard. The situation in the study area is not different from the general condition that needs strategic interference to reduce multidimensional poverty.

Poverty in Ethiopia is a multidimensional problem in which a single approach cannot be followed to eradicate it (Wolday, 2001). Ethiopia, as one of the least developed country, has applied different developmental strategies to reduce poverty and improve living standard. Among other things, microfinance is one of the mechanisms used to reduce multidimensional poverty. There is an established fact that if microfinance services are accessible to the poor, it would facilitate reduction of poverty by generating income and encourage investment (Kasali, Ahmed and Ean, 2015).

However, the role of microfinance services on poverty, health, living standard and education is inconclusive and debatable. On one hand, most empirical studies advocate the success stories of microfinance in reducing poverty, improving health condition \& living standard, promoting access to education for households. Microfinance has increased household expenditure for low income earners and marginalized groups which helped them to improve their living standards (Tegegn, 2015, Abur and Torruam, 2012). It was found that microcredit was important in increasing household income and expenditure that in turn has a positive effect on asset building.

Tsegaye (2014) has studied 120 households' poverty status in Gozamen wereda and revealed that microfinance is an important tool to reduce poverty which is negatively correlated with poverty status. On average, poverty has declined by $2 \%$ for credit users. We can infer that a household utilizing credit is able to either financing 
farm input purchases and other immediate food and non-food requirements or investing to different income generating activities expecting profit in the long run which ultimately lead them to exit poverty (Tsegaye, 2014). However, Tsegaye's poverty measurement was based on one dimensional (CBN) approach and this study has applied MPI for poverty measurement.

Microfinance has positive impact in building assets, like house, and improving living standards. Improvement in houses will also improve living standards of households by improving the wall of the house and installing electricity which are indicators of multidimensional poverty index (Bamlaku, 2004).

On the other hand, scholars' advocate microfinance services are not significant in reducing poverty, access to education, improving living standard and health condition. Lack of access to education is one of the major problems facing poor households in Ethiopia. Though there was no established relationship between education and microfinance, recent studies have found that microfinance is insignificant on access to education in Ethiopia. In rural Ethiopia primary and secondary education are usually free, although related costs are covered by families. Evidences indicated that the impact is more prevalent to females than males (Tazorri, Desai and Johnson, 2014).

Formal credit is given for an intended purpose to the poor so as to reduce their poverty level and improve standard of living. But it is diverted to needs that are not compatible with the intended objectives. Most poor households face substantial food shortage which cannot be covered by their production so that substantial amount of credit is diverted to meet food expenses and other basic needs. Credit has also a negative impact on asset building of poor households. Poor households sell their livestock and properties to repay the loan. This makes most poor household poorer than before (Dagnachew, Hilhorst and Pankrust, 2012).

Generally, the role of microfinance services on living standard, education, health status and hence multi dimensional poverty is in a debate. In addition to this, there are no many studies on multidimensional poverty in Ethiopia in general and in Gozamen wereda in particular. All the previous studies, described in this study, were done on one-dimensional poverty measurement which tells us only part of the situation. These reasons motivated us to do a research on the topic

\section{Research Method}

\subsection{Research Design}

Gozamen district is situated in East Gojjam zone of Amhara regional state of Ethiopia. It is located in the south west part of the zone between $37^{0} 23^{\prime} 50^{\prime}$ ' E latitude and $37^{0} 55^{\prime} 03$ ' $10 \mathrm{E}$ and $10^{\circ} 00^{\prime} 50^{\prime}$ ' $\mathrm{N}$ and $10^{\circ} 41^{\prime} 10^{\prime \prime} \mathrm{N}$, longitude. Gozamen is surrounded Machakel in the West, Debre Elias in the West, Bso Libes in the South East, Aneded in the East, Sinan, and Debaye Tilategen in the North. According to the Amhara bureau of finance and economic development, Gozamen district has a total population of 145,023 of which 71,339 are male and 73,683 are female. The total number of households accounts about 30,146. It has a total area of $1281,065,863$ with a population density of around 119 per square kilometer. Gozamen district has different landscapes, most of which are mountainous. The altitude ranges from $800 \mathrm{~m}-2400 \mathrm{~m}$ above sea level. This makes the district to have kola, Woyina Dega and Dega climatic regions. The majority of the populations' economic activity depends on agriculture. Around $97 \%$ of the population is dependent on agriculture. Only few have additional source of income from weaving, poetry and small business. Gozamen district is dominantly a food crop producing area of which Teff, Wheat and Maize are the most common outputs (Amhara bureau of finance and economic development, 2012).

The study followed quantitative research approach since the nature data for this study is quantitative nature. This study also investigates the poverty status of rural households and the extent of microfinance service on poverty status of rural household and hence, the researchers follow descriptive research design.

\subsection{Data Types, Sources and Methods of Data Collection}

The study employed primary data and the method of data collection was household survey collected by structured questioners.

\subsection{Sampling Techniques and Sample Size Determination}

The populations at which the samples were drawn are mostly located in rural areas. Probability sampling technique was used in the process of data collection. The population of Gozamen wereda is homogenous in many aspects except agro-ecological difference. Gozamen wereda has three climatic regions; Dega, Woina Dega and Kola agro-ecological zones. Based on this difference a stratified sampling technique was used to group the sample kebeles. There are 5 Dega, 2 Kola and 18 Woyna Dega kebeles.

A total of four kebeles were selected from the total kebeles of 25 using simple random sampling method, randomly drawn from a complete list of kebeles. One kebele each was selected from Dega and Kola areas while two kebeles were selected from the Woyna Dega area with the principle of proportional representation. A complete list of microfinance users and non-users was collected in each kebele and a proportional sampling was taken from both users and non users. The sample size was determined in proportion with the agro-ecological zones and the 
number of microfinance services user and non-user households.

Once the sample kebeles are identified, a sampling frame which contains a complete list of households (3202) was prepared and the sample determined using a simple formula (Cochran 1977).

$\mathrm{n}_{\mathrm{o}}=\frac{\mathrm{pqz2}}{\mathrm{e} 2}$

$\mathrm{P}$ is the estimated proportion of an attribute that is present in population which is incidence of poverty. $\mathrm{q}$ is $1-\mathrm{P}$, e is significance level $(5 \%), \mathrm{Z}$ is standard normal distribution $\left(\mathrm{z}^{2}=3.8146\right)$ and $\mathrm{n}$ is sample size. According to Tsegaye (2014) incidence of poverty in Gozamen wereda $(p)$ is 0.31 and q will be 0.69 .

Based on this, we have got 327 households. But when the sample size is more than $5 \%$ of the sample fame, Cochran (1977) suggested correction mechanism as; $\mathrm{n}=\frac{\mathrm{no}}{1+\mathrm{no} / \mathrm{N}}$

$\mathrm{N}$ is sample frame and $\mathrm{n}_{\mathrm{o}}$ is sample size in the original equation. By the correction mechanism, we have got 290 households. The sample for each kebele is obtained by using; $\mathrm{nk}=\frac{N k}{N t} * 290$ and the kebele sample is divided between microfinance service users and non-users in the same procedure.

The sampling procedure and sample size is seen in the following table.

Table 3.1:- Sampling procedure and sample size

\begin{tabular}{|c|c|c|c|c|c|c|c|c|}
\hline \multirow[b]{2}{*}{$\begin{array}{l}\text { Agro- } \\
\text { ecological zone }\end{array}$} & \multirow{2}{*}{$\begin{array}{l}\text { Number } \\
\text { of total } \\
\text { kebeles }\end{array}$} & \multirow{2}{*}{$\begin{array}{l}\text { Number of } \\
\text { selected } \\
\text { kebeles }\end{array}$} & \multirow{2}{*}{$\begin{array}{l}\text { Name of } \\
\text { selected } \\
\text { kebele }\end{array}$} & \multicolumn{2}{|c|}{$\begin{array}{l}\text { Number of households } \\
\text { by microfinance }\end{array}$} & \multicolumn{2}{|c|}{$\begin{array}{l}\text { Number of } \\
\text { sample }\end{array}$} & \multirow{2}{*}{$\begin{array}{l}\text { total } \\
\text { sample } \\
\text { size }\end{array}$} \\
\hline & & & & User & non-user & user & $\begin{array}{l}\text { non- } \\
\text { user }\end{array}$ & \\
\hline Dega & 2 & 1 & Enerata & 355 & 511 & 36 & 40 & 76 \\
\hline \multirow[b]{2}{*}{ Woina dega } & \multirow[b]{2}{*}{18} & \multirow[b]{2}{*}{2} & Addisnagulit & 352 & 474 & 36 & 38 & 74 \\
\hline & & & Yebo & 309 & 396 & 36 & 30 & 66 \\
\hline Kola & 2 & 1 & Chimet & 400 & 405 & 37 & 37 & 74 \\
\hline Total & 25 & 4 & & 1416 & 1786 & 145 & 145 & 290 \\
\hline
\end{tabular}

Source, 2017.

\subsection{Methods of Data Analysis and presentation}

The study used both descriptive statistics, and inferential statistics to analyze quantitative data. The descriptive statistic was summarized using average, and percentage to show the multidimensional poverty index, head count and intensity poverty. The data is presented in the form of table. For inferential statistics, propensity score matching model is used to examine the impact of micro finance service on multidimensional poverty status of beneficial rural households compare to that non beneficiaries in Gozamen district since the microfinance service were non randomly assigned for users .

\subsection{Variable Selection and Model Specification}

\subsubsection{Variable selection}

To measure the multidimensional poverty status the researcher use three dimensions of poverty such as education ,health and standard of livings and ten indicators of poverty as listed below ;

Depended variable

Head count of Mutidimestion Poverty (H):-multidimensional poverty head count status of each household as dummy dependent variable or outcome variable. It can be labeled 1 for poor 1 , other wise 0 . The cut of is head count is determined by when MPI equal to 0.33 and above the household considered as poor and other wise non -poor adopted from (OPHI, 2017). For the dimension of deprivation health, education and standard of living dimension is taken as outcome variables.

Treatment Independent Variable: Microfinance service as dummy 1 for users and zero other wise.

The independent variable or matching covariates are the followings;

Land size:-Cultivated land in hectare as continuous variable.

Family size: - number of peoples with the households as discrete variable.

Marital status:-as categorical variable

Sex:-as dummy variable 1 for male and 0 otherwise.

Age: - It is a continues variable

Education status of household heads: measured by year of schooling.

The study uses ten indicators of deprivation as follows;

Adult education deprivation:- Education Indicator-Years of Schooling, dummy variable $(0=\mathrm{ND}, 1=\mathrm{D})$.

Child education deprivation:-Education Indicator-School attendance, dummy variable $(0=\mathrm{ND}, 1=\mathrm{D})$.

Nutritional deprivation:-Health Indicator-Adult malnutrition $(0=\mathrm{ND}, 1=\mathrm{D})$, nutritional status is taken from the computation by using direct calorie intake of households. If the household takes less than the standard per capital 
nutritional requirement 2,100 calorie per adult per day set by the Ethiopian government the household is deprived(D), otherwise non- deprived(ND).

Child mortality:- Health Indicator - Child Mortality, $(0=\mathrm{ND}, 1=\mathrm{D})$.

Floor Derivation:-Standard of Living Indicator - Flooring or roof dirty material like grass $(0=\mathrm{ND}, 1=\mathrm{D})$

Sanitation deprivation:-Standard of Living Indicator-improved sanitation $(0=\mathrm{ND}, 1=\mathrm{D})$.

Access for clean water deprivation:-Standard of Living Indicator-Access for clean water $(0=\mathrm{ND}, 1=\mathrm{D})$. Given that less than 30 minute walk fetch and come to home.

Energy deprivation:-Standard of Living Indicator-Cooking Fuel $(0=\mathrm{ND}, 1=\mathrm{D})$

Elcctric city deprivation:-Standard of Living Indicator-Electricity $(0=\mathrm{ND}, 1=\mathrm{D})$.

Asset deprivation:-Standard of Living Indicator-Assets $(0=\mathrm{ND}, 1=\mathrm{D})$. Asset deprivation represents absence of least the following assets such as; television, Animal cart, and bicycle and farming tools

The weight of the above three dimensions and ten indicators will be adopted from OPHI 2017.

The methodology of computing MPI can be done as follows;

1. To choose the poverty deprivation cut off (identify which household is poor).

Each person is assigned a deprivation score according to his or her deprivation in the component indicators which lie between 1 and 0 . It can be expressed as;

$c_{i}=W_{1} I_{1}+W_{2} I_{2}+W_{3} I_{3}+W_{d} I_{d}$, where $\mathrm{I}=1$, if the person is deprived in indicator " $\mathrm{i}$ ", and $\mathrm{I}=0$, otherwise and $w_{i}$ is the weight attached to indicator " $i$ " with sum of weight equal to 1 . With any combination of the indicators any one will be multidimensional poor if and only if; MPI is greater than or equal to 0.33 , multidimensional poor.

2. Computing the MPI (aggregation).

i. Calculate the multidimensional poverty Head count $(\mathbf{H})$ : the percentage of people who are poor which shows the incidence of poverty. It can be expressed using the formula: $=\frac{q}{n}$ where " $\mathrm{q}$ " is the number of people who are multidimensional poor and " $n$ " is total population.

ii. Calculating the Intensity or Breadth of poverty (A):- It is the average deprivation score of multidimensional poor people or the average percentage of dimension in which the poor people are deprived. It can be expressed as;

$\mathrm{A}=\frac{\sum_{i=1}^{q} \operatorname{ci(K)}}{q}$, Where $\operatorname{ci}(\mathrm{K})$ is censored (for those whose deprivation score is below poverty cut off, even it is non-zero this is replaced by zero) deprivation score of individual ( $\mathrm{i}$ ), and $\mathrm{q}$ is the number of people who are multidimensional poor .

3. The Calculated multidimensional poverty index (MPI) for the study area measures the proportion of weighted that the poor experience in a society out of all the total deprivation that the society could experience. The MPI can also be broken down by indicators, which is a useful tool for public policy. It means that MPI itself is simply the percentage of people who are poor and deprived in each indicator multiplied by the weight on that indicator. it can be expressed as;

MPI =HX A, where " $\mathrm{H}$ " is head count ratio, and " $\mathrm{A}$ " is intensity ((OPHI), 2017).A person identified as poor if he /she is deprived in at least one third (33.33 percent) of the weighted indicators ((OPHI), 2017).

\subsubsection{Model specification}

The dependent variable is a dummy that takes a value of 1 when a household is multidimensional poor and 0 otherwise by using 0.33 as a cut off adopted from OPHI, 2017. To examine the impact of Microfinance service on multidimensional poverty status of rural households the propensity score matching model estimated with logit is used.

Estimating the average treatment effect can be as follows;

$$
\mathrm{ATE}=\frac{1}{N 1} \sum_{i=1}^{N 1}\left(y 1 i-\sum_{j=1}^{N 0} w_{i j y o j}\right)
$$

$$
\text { Where, } w_{\mathrm{ij}} \in[0,1] \text { and } \sum_{j=1}^{N o} w i j=1
$$

$\mathrm{N}_{1}$ is number of participants and $\mathrm{N}_{\mathrm{o}}$ is number of nonparticipants

$\mathrm{i}$ index of participants and $\mathrm{j}$ index of nonparticipants

Wij weights.

\section{RESULT AND DISCUSSION}

\subsection{Descriptive statistics}

\subsubsection{Multidimensional poverty status of Rural Households in Gozamen District}

This study found that 73.81 percent of rural peoples in Gozamen district are multidimensional poor, on average the poor people are deprived in 49.18 percents of the weighted indicators and the society is deprived in 36.30 percent of the total potential deprivation it could experience over all. Rural households in Gozamen district are deprived at least either all indicator of a single dimensions or a combination across dimensions such as being in a 
household with a malnourished person, no electricity, no access for clean water, shared sanitation .This result shows that the poverty status of rural households in Gozamen district is moderately poor. However in rural Ethiopia 96.30 percent of peoples are multidimensional poor, on average, the poor people are deprived 66.20 percents of the weighted indicators and the society is deprived in 63.7 percent of the total potential deprivation it could experience over all and hence, the multidimensional poverty status of rural Ethiopia is classified under extremely poor ((OPHI), 2017).

\begin{tabular}{ll} 
Table 3-1: Contribution of each dimension to multidimensional poverty \\
\hline Dimension of deprivations & Total \\
\hline Education deprivation & 0.2624 \\
Heath deprivation & 0.1249 \\
Standard of living deprivation & 0.6127 \\
\hline Total & 1 \\
\hline
\end{tabular}

Source: own survey, 2017

The above table shows that the highest contribution to multidimensional poverty status of rural households in Gozamen District is standard of living deprivation which accounts 61.27 percent followed by education deprivation 26.24 percent and health deprivation 12.49 percent respectively. The data shows that standard of living take the largest domain of multidimensional poverty status of rural households in the sampled area of Gozamen district .The finding of the study confirm with (Andualem, 2016).

Table 3-2: Contribution of indicator to multidimensional poverty status

\begin{tabular}{ll}
\hline Indicators of deprivations & Total \\
\hline Adult education deprivation & 0.253 \\
Child education deprivation & 0.00937 \\
Child mortality deprivation & 0.03592 \\
Nutrition deprivation & 0.08902 \\
Sanitation deprivation & 0.1052 \\
Energy deprivation & 0.113 \\
Clean water deprivation & 0.1041 \\
Floor deprivation & 0.113 \\
Assets deprivation & 0.06767 \\
Electricity deprivation & 0.1098 \\
\hline \multicolumn{2}{c}{ Source: own survey, 2017. }
\end{tabular}

From the above table the highest share of multidimensional poverty highly comes from adult education, energy and floor having equal share, electricity, asset, clean water, sanitation, nutrition, child mortality and child education deprivation respectively.

3.1.2 Decomposition of multidimensional poverty by access for microfinance service

Table 3-2-2: Decomposition of multidimensional poverty by micro finance service beneficial status

\begin{tabular}{lll}
\hline Poverty status & Microfinance Non-Beneficiaries & Microfinance Beneficiaries \\
\hline H & 0.8216 & 0.5963 \\
A & 0.504 & 0.4632 \\
Mo & 0.4141 & 0.2762
\end{tabular}

Pearson $\operatorname{chi} 2(1)=18.0088 \operatorname{Pr}=0.000$

Source: own survey, 2017

The above that show that in Gozamen district 82.16 percent of microfinance non- beneficiariesand 59.63 Microfinance Beneficiaries peoples are multidimensional poor and the intensity of multidimensional poverty for microfinance service beneficial and non users of micro finance service were 46.32 percent and $50.4 \%$ respectively. The research result also shows that the non users of microfinance financial service were moderately poor i.e deprived in 41.41 percent and the member's society was deprived while users of microfinance service 27.62 percent deprivation of the total potential deprivation it could experience overall which shows that the users of the service were vulnerable to poverty or at risk of poverty. The chi2 test shows that there is an association between multidimensional poverty status and microfinance financial service at $1 \%$ significance level.

Table 3-2-3: Contribution of domain to poverty status by microfinance service beneficial status

\begin{tabular}{|c|c|c|c|c|c|}
\hline Dimension of deprivation & $\begin{array}{l}\text { Microfinance } \\
\text { Beneficiaries }\end{array}$ & service & Non- & $\begin{array}{l}\text { Microfinance } \\
\text { Beneficiaries }\end{array}$ & service \\
\hline Education deprivation & 0.3028 & & & 0.1938 & \\
\hline Health deprivation & 0.1489 & & & 0.08425 & \\
\hline Standard of livings deprivation & 0.6891 & & & 0.483 & \\
\hline Total & 1.141 & & & 0.761 & \\
\hline
\end{tabular}

Source: own survey, 2017. 
The above table shows that the highest contribution to multidimensional poverty index is standard of living for both microfinance service users and non users in Gozamen district which accounts about 68.91percent for microfinance financial service non users and 48.30 percent for microfinance financial service users.

The second highest contribution domain to poverty status of rural household in the study area is Education which accounts 30.20 percent for microfinance financial service non users and 19.38 percent for users.

The third contribution domain to poverty status of rural household is education which accounts 14.89 percent for microfinance service users and 8.425 percent for microfinance service users. The data shows that standard of living is a serious problem for both in the sample of rural households. However, relatively the in all domains of multidimensional poverty the users of microfinance service is relatively lower than non- users.

Table 3-2-4: Contribution of indicator to poverty by membership status

\begin{tabular}{lll}
\hline Indicators of deprivation & $\begin{array}{l}\text { Microfinance } \\
\text { Non- Beneficiaries }\end{array}$ & $\begin{array}{l}\text { Microfinance } \\
\text { Beneficiaries }\end{array}$ \\
\hline Adult education deprivation & 0.2929 & 0.1853 \\
child education deprivation & 0.009927 & 0.008425 \\
Nutrition deprivation & 0.09927 & 0.07161 \\
Child mortality deprivation & 0.04964 & 0.01264 \\
Floor deprivation & 0.1257 & 0.09127 \\
Sanitation deprivation & 0.1175 & 0.08425 \\
Clean water deprivation & 0.1175 & 0.08144 \\
Energy deprivation & 0.1257 & 0.09127 \\
Electricity deprivation & 0.1233 & 0.08705 \\
Asset deprivation & 0.07942 & 0.04774 \\
\hline Total & 1.141 & 0.761 \\
\hline Source: own survey
\end{tabular}

Source: own survey, 2017.

The highest indicators of multidimensional poverty was adult education for both micro followed by floor.

However, the lowest indicators of deprivation are child education for both Microfinance service non -beneficiaries and beneficiaries.

\subsection{Inferential statics}

Before estimating the average treatment on the treated the following basic assumptions were checked as a prerequite the common support assumption were checked by kernel density plot, which ensures that there is sufficient overlap in the characteristics of treated and non treated units to find adequate match which shows a lots of support between red and blue line (see appendix 2).

To check the pstest were checked for balancing before trusting the ATT estimation and after matching, it was non-significant, so that the balancing was good for this study in building the good control group. The average absolute bias before matching was 8 and after matching it becomes 2.4 and hence the overall matching performance is good for all covariates (please see appendix 3).

Furthermore, Mantel Haenszel test statistics $(\mathrm{MH})$ sensitivity analysis for average treatment effect were checked and there are no unobserved variable that affects treatment in to and the outcome variable simultaneously which might not arise hidden bias to which matching estimators are robust(see appendix ,4) .

3.2.1 The impact of microfinance on poverty status of rural households in Gozamen District

Table 4.2.2.1: The average treatment effect on treated multidimensional poverty head count

\section{Variable Sample Treated Controls Difference S.E. T-stat}

$\begin{array}{lllllll}\text { Headcount Unmatched } & .593103448 & .882758621 & -.289655172 & .048935018 & -5.92\end{array}$

ATT \begin{tabular}{llllll}
.593103448 & .770497457 & -.177394009 & .054530891 & -3.25 \\
\hline
\end{tabular}

Source: own survey, 2017.

The above output shows that negative treatment effect on their multidimensional poverty head count of rural households(-0.177394009) difference is brought due to Microfinance service intervention for users compare to that of non users and statistically significant at 1 percent level of significance. Alternatively, rural household of the treatment group, the treatment has reduced their multidimensional poverty head count by 0.177394009 on average.

The explanation is that microfinance provides, loan and training service in Gozamen district as clearly stated in descriptive part of the study. Hence, the users of this, microfinance program used for summer season crop production, pity trade, animal fattening, current consumption, irrigation and horticulture activity respectively which in turn leads to reduction multidimensional status of household. This finding confirms to (Tsgay, 2014), (Adekola, G. and Dokubo,Chidinma, 2017) and (Eleuter Atilio Kihwele and Raphael Gwahula, 2015, Adams \& Von Pischke, 1992; Coleman, 1999; Schicks \& Rosenberg, 2011). 
1) Standard of Living Dimension

Table 4.2.2.2: The average treatment effect on treated standard of living dimension

Variable Sample Treated Controls Difference S.E. T-stat

Standard of living Unmatched $2.8424827 \quad 3.01627579-.173793087 \quad 044951596 \quad-3.87$

\begin{tabular}{llllll} 
ATT & 2.8424827 & 2.97566064 & -.133177934 & .052135009 & -2.55 \\
\hline
\end{tabular}

Source: own survey result, 2017.

As clearly shown in the table above the impact of microfinance service for standard of living is statistically significant that the individual of the treatment group, the treatment has reduced standard of living deprivation by -0.133177934 on average. The explanation is that the rural household who are users of microfinance programme for the purchase of radio, television, and car and creates access for electricity, other assets and few energy sources which is a means for future production as well as raises their current consumption and their by reduce the standard of living dimension of poverty .

2) Educational Dimension:-It consists of child education and adult education indicators of poverty.

Table 4.2.2.3: the average treatment effect on treated educational dimension

\begin{tabular}{rrrrrrr} 
Variable & Sample & Treated & Controls & \multicolumn{1}{c}{ Difference } & \multicolumn{1}{c}{ S.E. } & \multicolumn{1}{c}{ T-stat } \\
\hline Education Unmatched & .065648274 & .125537928 & -.059889654 & .00964557 & -6.21 \\
ATT & .065648274 & .08004803 & -.014399756 & .011337335 & -1.27 \\
\hline & & &
\end{tabular}

Source: own survey result, 2017.

Note: ATT is average treatment effect on the treated

The output shows that for the individual of the treated group, the treatment has reduced the educational deprivation by -0.014399756 on average. The explanation is that the availability of microfinance service allow the users to cover the costs of education and their by rise year of schooling and school attendance and their by reduce child education and adult education indicator of multidimensional poverty status of rural households.

3) Health Dimension:-It consists of two indicators of poverty i.e nutrition and child mortality.

Table 4.2.2.4: The average treatment effect on treated health dimension

Variable Sample Treated Controls Difference S.E. T-stat

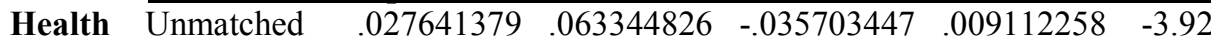

\begin{tabular}{llllll} 
ATT & 027641379 & 070831489 & -.04319011 & .011223225 & -3.85 \\
\hline
\end{tabular}

Source: own survey result, 2018.

The output shows that for the households of the treated group, the treatment has reduced the health dimension of poverty by -0.04319011 on average. The explanation is that the prevailing financial availability for users of the programme allows reducing child death and increasing expenditure on food, which in turn prevent infectious disease as well as improving nutritional status of children's and their by reduce the health dimension of poverty .The finding confirms (Nuredin Mohammed, Byeong Wan Le, 2015) .For the validity of the average treatment effect.

\section{SUMMARY, CONCLUSION AND RECOMMENDATION 4.1 Summary and Conclusion}

This study found that 73.81 percent of rural peoples in Gozamen district are multidimensional poor, on average the poor people are deprived in 49.18 percents of the weighted indicators and the society is deprived in 36.30 percent of the total potential deprivation it could experience over all. Rural households in Gozamen district are deprived at least either all indicator of a single dimensions or a combination across dimensions such as being in a household with a malnourished person, no electricity, no access for clean water, shared sanitation however ,the poverty status of Gozamen district is classified as moderately poor .

The highest contribution to multidimensional poverty status of rural households in Gozamen District is standard of living deprivation which accounts 61.27 percent followed by education deprivation 26.24 percent and health deprivation 12.49 percent respectively. The data shows that standard of living take the largest domain of multidimensional poverty status of rural households in the sampled area of Gozamen district.The finding of the study confirm with Andualem ,2016; Obadia, 2014; Oluyombo, 2013;Adekola, G. and Dokubo,Chidinma , 2017 etc.

The propensity score matching model result reveled negative treatment effect on their multidimensional poverty head count of rural households(-0.177394009) difference is brought due to Microfinance service intervention for users compare to that of non users and statistically significant at 1 percent level of significance.

It is also found that microfinance service has reduced standard of living deprivation by -0.133177934 , health deprivation by- 0.04319011 and education deprivation by 0.014399756 on average for treated compare to that of non treated group in Gozamen district. This finding confirms to (Odoyo, 2012),(Obadia, 2014),(Oluyombo, 2013) and (Adekola, G. and Dokubo,Chidinma , 2017)etc. 


\subsection{Recommendation}

Based on this research finding, the researcher forwards the following recommendations;

Microfinance service has a negatively impact on the multidimensional poverty status of rural household and hence, the government should give special attention to support microfinance those who support the rural poor household heads and improve the awareness level of farmers about it. Additionally, the microfinance financial institution expert should give attenstion for health, education and standard of living respectively to improve the dimension of deprivation multidimensional poverty. Furthermore, the rural households shall use microfinance service for health improvement, education improvements and standard of living improvements so as to reduce their multidimensional poverty in Gozamen district.

\section{Reference}

Abur, Clement, Torruam and Terande (2012). Microcredit as a Strategy for Poverty Reduction in Makurdi Local Government Area of Benue State, Nigeria. International Journal of Humanities and Social Science, 2(12), 181-186.

Adams, D. W., \& Von Pischke, J. D. (1992). Microenterprise credit programs: Deja vu. World development, 20(10), 1463-1470. Retrieved 2017-10-1from: http://www.sciencedirect.com/science/article/pii/0305750X92900665 . (n.d.).

Adane Atara (2010). Assessment of the Role of Microfinance in Rural Household's Food Security: The Case of Omo Microfinance in Dale Woreda. Addis Ababa University: Addis Ababa.

Ahmed Mohamed Tahir (2015, online). The Challenges Facing Microfinance Institutions in Poverty Eradication: A Case Study in Mogadishu. International Journal of Humanities, Social Sciences and Education, 2(2), 5759

Alemayehu Yirsaw (2008. The Performance of Microfinance Institutions in Africa. Addis Ababa University: Addis Ababa.

Alessandro Tazorri, Jaikishan Desai \& Kristin Johnson (2014, March). Impacts of Microcredit: Evidence from Ethiopia. Journal of Social Science, 24-28.

Amhara Bureau of Finance and Economic Development, (2012). $8^{\text {th }}$ report: Development Indicators of Amhara Region. Retrieved from http://www.amharabofed.gov.et, accessed 16 December 2016.

Amogne Asfaw (2014). Microfinance as a Pathway out of Poverty and Viable Strategy for Livelihood Diversification in Ethiopia. E3 Journal of Business Management and Economics, 5(6), 145-150.

An Abridged Guide to the APA Referencing Style ( $6^{\text {th }}$ edition). (2010). CQ university Academic Learning Service Unit: Australia.

Anderibom and Asauten Samuila (2015). An Assessment of the Roles, Challenges and Prospects of Microfinance Banks in Nigera: Evidenced from Yola. International Journal of Education and Research, 3(2), 451-455.

Andualem Goshu (2016). A Panel Multidimensional Estimation for Ethiopia. University of Milan: Italy.

Andualem, G. (2016). "A panel Mutidimesional Estiamtion for Ethiopia". University of Milan :Italy

Antawi, B. D. (2015). "Microfinace and poverty reduction in Gahana" : Evidance from the Dorma area teachers cooperative Union in Dorma Muncipality Brong Ahafo

Anteneh Basaznew (2008). Gender and Agricultural Production in Ethiopia: The Case of Gozamen Woreda. Addis Ababa University: Addis Ababa.

Appah Ebimobowei, John M. Sophia and Sorem Wisdom (2012, March). An Analysis of Microfinance and Poverty Reduction in Bayelsa state of Nigeria: Kuwait Chapter of Arabian Journal of Business and Management Review, 1(7), 48-53.

Arion Blas (2011). Financial Access and Consumption Smoothing in Indonesia. Unpublished master thesis: Wesleyan university: Indonesia.

Asad K.Ghalib, I. M. (2011). "The impact of microfinace and its role in easing poverty rural households :estimation from pakistan" : Research Institute for Economics and bussiness Adminstartion, Kobe Universoity .

Aschale Dagnachew, Dorothea Hilhorst and Alula Pankhurst( 2012, in press). The Differential Impact of Microcredit on Rural Livelihoods: Case study from Ethiopia.

Aziza Geleta Dessalegn (2013). The Role of Microfinance in Poverty Reduction: The case of Specialized Financial Promotion Institute (SFPI). Unpublished master's thesis: Addis Ababa University: Addis Ababa.

Bamlaku Alamirew(2004). Microfinance and Improvement in Living standards: a Pathway out of Poverty (the case of Enemay Woreda). Addis Ababa University: Addis Ababa.

Bartlett, James E., Kotrlik, Joe.W.,and Higgins, Chadwick. (2001). "Organizational Research: Determining Appropriate Sample Size in Survey Research”. Information Technology, Learning, and Performance Journal, 19(1), 44-50.

Beatriz Armendariz and Jonathan morduch (2010). The Economics of Microfinance. Massachusetts Institute of technology: London. 
Bismark Dwommor (2015). Microfinance and Poverty Reduction in Ghana, Dorma Municipality. Norwegian university of life science: Norway.

Caroline Dotter and Stephan Klasen (2014). The Multidimensional Poverty Index: Achievements, Conceptual and Empirical Issues. United Nations Development Program: United Nations.

Daba Moti (2003). The Impact of Microfinance on Poverty Reduction in Eastern Wellega zone: the Case of Oromiya Credit and Saving Institution. Unpublished Master Thesis, Addis Ababa University: Addis Ababa.

Dan Matovu (2006). Microfinance and Poverty Alleviation in Uganda: a case study of Uganda Finance Trust. Unpublished Master's Thesis, Goteborg's University: Uganda.

Daniel C. Hardy, Paul Holden and Vassili prokopenko(2002). Microfinance Institutions and Public policy (report number wp/02/159). IMF: Washington D.C.

Degefe Duressa (2009). Microfinance in Ethiopia, Elixir or Poison? Unpublished doctoral Dissertation, The Hague: Netherland.

Denis Lewa Muganga (2010). The Role of Regulation and Supervision of Microfinance Institutions: Evidence from South Africa, and Its Implications for the Development of Non-Deposit Taking Microfinance Regulation in Kenya. University of Bergamo: Italy.

Eshetu Seid and Gian Singh (2015). Determinants of Farm Household Poverty Status in South Wollo Zone, Amhara Regional state, Ethiopia. International Journal of Research in Economics and Social Sciences, 6(11), 325-328.

Esubale Alehegn (2006). Determinants of Urban Poverty in Debre Markos, Ethiopia: A Household Level Analysis. Addis Ababa University: Addis Ababa.

Farhad Hossain and Tonya Knight (2008). Financing the Poor: Can Microcredit Make a Difference? Empirical Observations from Bangladesh. The University of Manchester: Manchester.

Fitsum Aklilu (2013). Assessing the Impact of Productive Safety Net Program on Asset Building and Sustainable Land Management Practices: a Cross Sectional Analysis from Eastern Hararghe. Mekele University: Mekele.

Gosa Setu Tafese (2014, online). The Role of Microfinance Institutions in Poverty Reduction and Women's Empowerment in Ethiopia: The Case of Dedibit Credit and Saving Institution. Research on Humanities and Social Sciences, 4(16), 41-44. Retrieved from http://www.iiste.org, accessed 25 January 2017

Guush Berhane and Cornelis Gardebroek. (Augest ,2012). "Does Microfinance reduce rural poverty?" evidence based on Household Panel data from Northern Ethiopia. accessed on november 22/2017 http://ajae.oxfordjournals.org/Downloaded fro .

Hailai Abera (2010). Can Microfinance Help to Reduce Poverty in Tigray Region? Mekele University: Mekele. Jennefer sebstad(2003). Short Study on Microfinance: Ethiopia (report no. SIDA2136en). Addis Ababa: Ethiopia Joanna Ledgerwood (1999). Sustainable Banking with the Poor, Microfinance Handbook (ISBN 0-8213-4306-8). The World Bank, Washington D.C

Kiros Habtu Ferede (2012). Determinants of Rural Households Demand for and Access to Credit in Microfinance Institutions: The Case of Alamata Woreda-Ethiopia. Unpublished Doctoral Dissertation, Groningen University: Netherland.

Manfred Zeller (1999, February). The Role of Micro-Finance for Income and Consumption Smoothing: Paper Presented at the Social Protection and Poverty Conference, Washington D.C.

Mehrteab H.T (2005). Adverse Selection and Moral Hazard in Group-Based Lending: Evidence from Eritrea. University of Groningen: Netherland.

Michael Chiba (2009). Financial Inclusion, Poverty Reduction and the Millennium Development goals: Canadian International Development Consultants, Inc., Canada. EuropeanJjournal of Development Research, 21, 214 280. doi:10.1057/ejdr.2008.17

Michal Kowalik and David Martinez-Miera (2010).The Creditworthiness of the Poor: A Model of the Grameen Bank. Federal Reserve Bank of Kansas City: Spain.

Ministry of Finance and Economic Development (2013). Federal Democratic Republic of Ethiopia. Development and Poverty in Ethiopia: Addis Ababa.

Morduch, J. (1998). "Does microfinance really help the poor?": New evidence from flagship programs in Bangladesh. Research Program in Development Studies, Woodrow School of Public and International Affairs. . (n.d.).

Mwewa Naomi Mbithe (2013). The Effect of Microfinance Services on the Growth of Small and Medium Scale Enterprises in Machakos County. University of Nairobi: Nairobi.

Olga Torres Garcia (2009). Measuring Poverty and Vulnerability in Microfinance. University of Madrid: Spain.

OPHI), O. P. (2017). Ethiopia Country Briefing”, Multidimensional Poverty Index Data bank. Oxford Department of International Development.

Oxford Poverty and Human Development Initiative (2014)."Ethiopia Country Briefing”. OPHI: University of Oxford. Retrieved from www.ophi.org.uk/multidimensional poverty index/, accessed 13 December 2016.

Phetsile Dlamini and Neil Brislin (2006). Amhara Credit and Saving institutions: Ethiopia, USAID Financial 
Service Knowledge Generation (report number micro report 58).

Pitt, M. M., \& Khandker, S. R. (1998). "The impact of group-based credit programs on poor households in Bangladesh: Does the gender of participants matter?. Journal of political economy, 106(5), 958-996. Retrieved 2017-01-12 from: http://www.journals .uchic. (n.d.).

Sabina Alkire and James Foster (2011).Understandings and Misunderstandings of Multidimensional Poverty measurement. OPHI working paper No. 43: Oxford Department of International Development: University of oxford.

Sabina Alkire and Maria Emma Santos (2010). Acute Multidimensional Poverty: A New Index for Developing Countries. OPHI Working Paper no.38: University of Oxford.

Sabina Alkire, James E. Foster, Suman Seth, Maria Emma Santos, Jose M. Roche and Paola Ballon (2015). Multidimensional Poverty Measurement and Analysis: Robustness Analysis and Statistical Inference. OPHI working paper 89: university of Oxford.

Samuel Kwadwo Frimpong and Nguerenomo Kalbersonn (2014). Assessing the Contribution of Microfinance Institutions to Poverty Reduction in Ghana: A Case Study of the Christian Rural Aid Network (CRAN). Ghana International Journal of ICT and Management, 2(2), 121-123.

Sara Horrell and Pramila Krishnan (2006). Poverty and Productivity in Female-Headed Households in Zimbabwe. Faculty of Economics, University of Cambridge: Cambridge.

Schicks, J., \& Rosenberg, R. (2011). Too Much Microcredit?: A Survey of Issues and Evidence on OverIndebtedness among Micro-Borrowers. CGAP Occasional Paper. Retrieved 2017/02/1 from: http://documents.worldbank.org/curated/en/553421468148522571/Toomuch-m. (n.d.).

Shimelles Tenaw \& Zahidul Islam (2009). Rural Financial Services and Effects of Rural Financial Services on Agricultural Productivity and on Poverty. University of Helsinki: Helsinki.

Sindu Werkineh (2013). Dynamics and Drivers of Consumption and Multidimensional Poverty: Evidence from Rural Ethiopia. University of Berlin: Germany.

Stefen Staschen (2003). Regulatory Requirements for Microfinance: A Comparison of Legal Frameworks in 11 Countries Worldwide. Retrieved from http://www.gtz.de, accessed 1 December 2016.

T. G. Apata, O. M. Apata, O. A. Igbalajobi and S. M. O. Awoniyi . (September 2010 ). Determinants of rural poverty in Nigeria: Evidence from small holder farmers in South-western, Nigeria . Journal of Science and Technology Education Research Vol. 1(4), , pp. 85 - 91.

Taofeek Aremu Kasali, Siti Aznor Ahmad and Lim Hock Ean (2015). Does Microfinance Operation have Effect on Poverty Alleviation in Nigeria? European Journal of Contemporary Economics and Management, 2(2), 54.

Tegegn Nigussie (2015). Impact of Amhara Credit and Saving Institution on Income, Expenditure and Asset Holdings of Households: the case of Rural kebeles of Woldia District, North Wollo zone. Haramaya University: Haramaya.

Teuta Cerpja and Forcim Kola (2015). Income and Consumption Smoothing as an Impact of Microfinance: case of Albania. International Journal of Management and Business Economics, 4(4), 21-25.

Tripti Srivastava (2010). Microfinance: A Comparative Analysis of Varying Contexts, Current Needs, and Future; Prospects between Developing and Developed Countries. Unpublished Doctoral desertation, Bowling Green State University: India.

Tsegaye Molla (2014). Household Level Analysis of Rural Poverty: The case of Gozamen District of East Gojjam zone. Haramaya University: Haramaya.

United Nations Human Rights Commission (2012). What is Poverty? Retrieved from http://www.ohchr.org/Documents/Publications/Poverty Strategies, accessed 10 February 2017

United Nations Millennium Project (2015). Fast facts: the Faces of Poverty. Retrieved from http://www.numillniumproject.org, accessed 10 February 2017.

United Nations Statistics Division (2005). Handbook on Poverty Statistics: Concepts, Methods and Policy use.

William Angko(2013, online). Microfinance and Poverty Reduction Nexus among Rural Women in Selected Districts in the Upper West Region of Ghana, 3(9), 134-137 retrieved from http://www.iiste.org, accessed 25 December 2016

William Cochran (1977). Sampling Techniques: Third Edition: Harvard university. John Wiley and Sons Publishing Inc.

Wolday Amha (2000). Review of Microfinance Industry in Ethiopia: Regulatory Frameworks and Performance. Paper Presented in a Conference Prepared by Association of Ethiopian Micro Institutions: Addis Ababa

Wolday Amha (2001). Poverty Assessment in Ethiopia: the Experience of Microfinance in Poverty Reduction, Association of Ethiopian Microfinance Institutions. Paper Presented in a Conference Prepared by UN Economic Commission for Africa: Addis Ababa.

World Bank Poverty Manual (2005). Methods and Measurement of poverty: Washington D.C 
Appendix 1: Average treatment effect on the treated

. psmatch2 Micservi Land Age Famsize Hhedu Marstau SEX, kernel outcome

Probit regression

Log likelihood $=-183.84389$

$\begin{array}{llr}\text { Number of obs } & = & 290 \\ \text { LR chi2 (6) } & = & 34.34 \\ \text { Prob > chi2 } & = & 0.0000 \\ \text { Pseudo R2 } & = & 0.0854\end{array}$

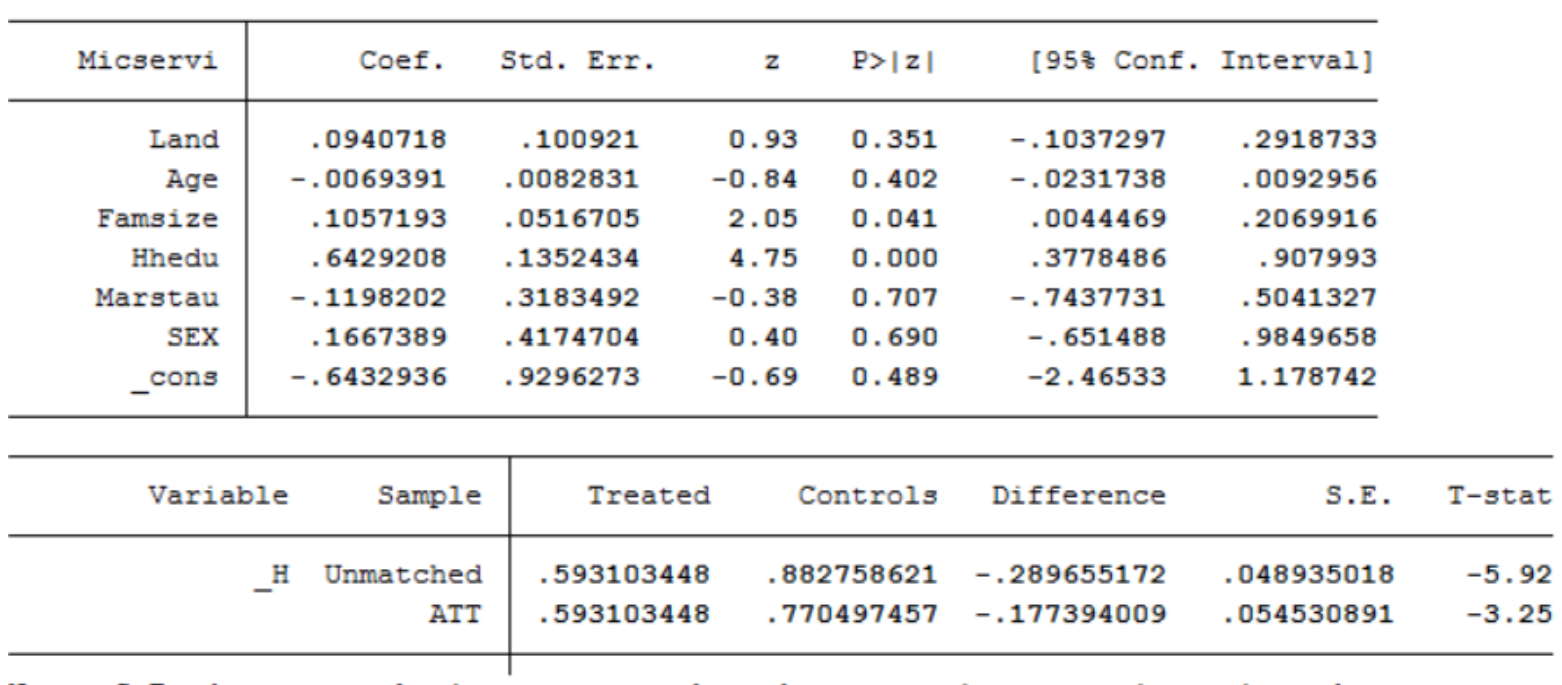

Note: S.E. does not take into account that the propensity score is estimated.

\begin{tabular}{|c|c|c|}
\hline $\begin{array}{l}\text { psmatch2: } \\
\text { Treatment } \\
\text { assignment }\end{array}$ & $\begin{array}{c}\text { psmatch2: } \\
\text { Common } \\
\text { support } \\
\text { On suppor }\end{array}$ & Total \\
\hline Untreated & 145 & 145 \\
\hline Treated & 145 & 145 \\
\hline Tota. & 290 & 290 \\
\hline
\end{tabular}


Probit regression

Log likelihood $=-183.84389$

$\begin{array}{llr}\text { Number of obs } & = & 290 \\ \text { LR chi2 (6) } & = & 34.34 \\ \text { Prob > chi2 } & = & 0.0000 \\ \text { Pseudo R2 } & = & 0.0854\end{array}$

\begin{tabular}{|c|c|c|c|c|c|c|c|c|}
\hline Micservi & & Coef. & Std. Err. & z & $\mathrm{P}>|\mathrm{z}|$ & [95\% Conf. & Interval] & \\
\hline Land & & .0940718 & .100921 & 0.93 & 0.351 & -.1037297 & .2918733 & \\
\hline Age & & -.0069391 & .0082831 & -0.84 & 0.402 & -.0231738 & .0092956 & \\
\hline Famsize & & .1057193 & .0516705 & 2.05 & 0.041 & .0044469 & .2069916 & \\
\hline Hhedu & & .6429208 & .1352434 & 4.75 & 0.000 & .3778486 & .907993 & \\
\hline Marstau & & -.1198202 & .3183492 & -0.38 & 0.707 & -.7437731 & .5041327 & \\
\hline SEX & & .1667389 & .4174704 & 0.40 & 0.690 & -.651488 & .9849658 & \\
\hline _cons & & -.6432936 & .9296273 & -0.69 & 0.489 & -2.46533 & 1.178742 & \\
\hline \multicolumn{3}{|c|}{ Variable } & \multicolumn{2}{|c|}{ Treated } & Controls & Difference & S.E. & T-stat \\
\hline \multirow{2}{*}{\multicolumn{2}{|c|}{ heath }} & Unmatched & .027641 & \multicolumn{2}{|c|}{.063344826} & -.035703447 & .009112258 & -3.92 \\
\hline & & ATT & .027641 & \multicolumn{2}{|c|}{.070831489} & -.04319011 & .011223225 & -3.85 \\
\hline
\end{tabular}

Note: S.E. does not take into account that the propensity score is estimated.

\begin{tabular}{r|r|r} 
psmatch2: & $\begin{array}{r}\text { psmatch2: } \\
\text { Common } \\
\text { Treatment } \\
\text { support }\end{array}$ \\
assignment & On suppor & Total \\
\hline $\begin{array}{r}\text { Untreated } \\
\text { Treated }\end{array}$ & 145 & 145 \\
\hline Total & 145 & 145 \\
& 290 & 290
\end{tabular}


Probit regression

Log likelihood $=-183.84389$

$\begin{array}{llr}\text { Number of obs } & = & 290 \\ \text { LR chi2 (6) } & = & 34.34 \\ \text { Prob > chi2 } & = & 0.0000 \\ \text { Pseudo R2 } & = & 0.0854\end{array}$

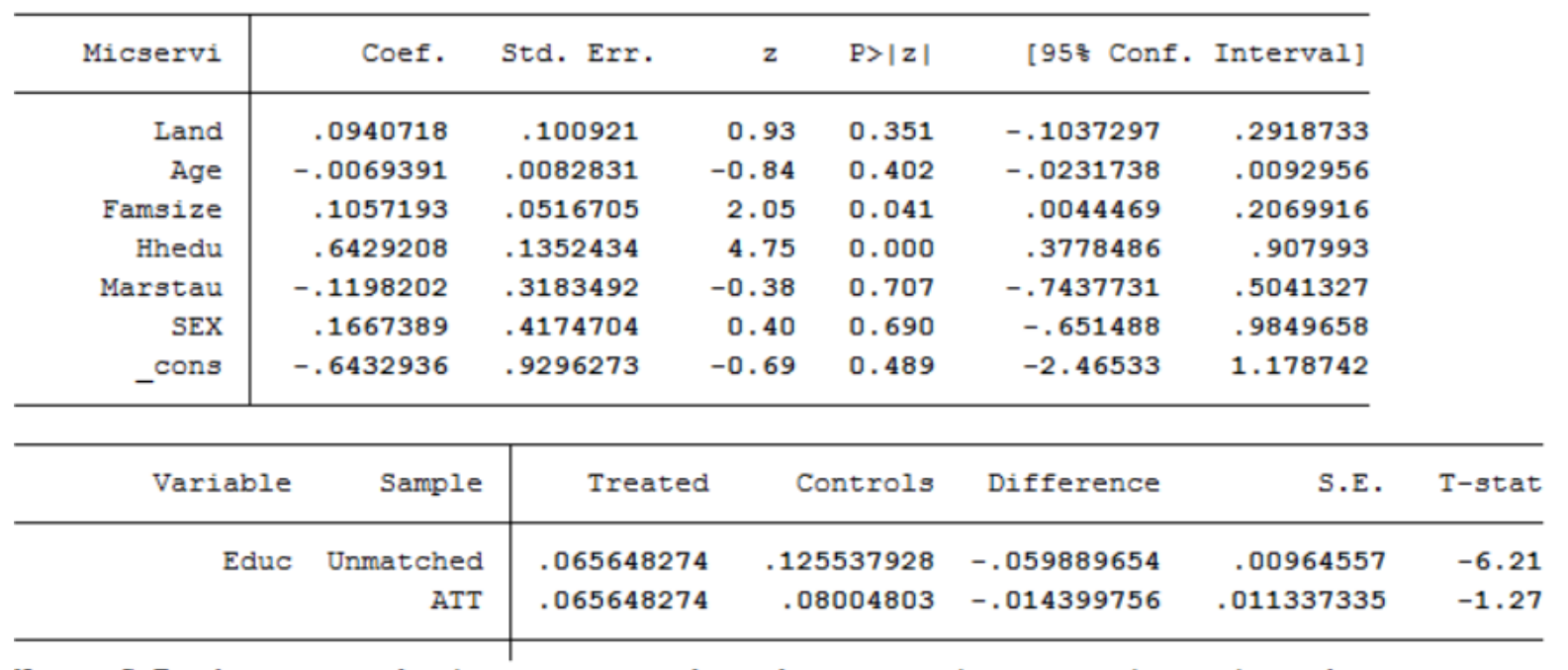

Note: S.E. does not take into account that the propensity score is estimated.

\begin{tabular}{r|r|r} 
psmatch2: & $\begin{array}{r}\text { psmatch2: } \\
\text { Common } \\
\text { Treatment } \\
\text { support } \\
\text { assignment }\end{array}$ & On suppor \\
\hline $\begin{array}{r}\text { Untreated } \\
\text { Treated }\end{array}$ & 145 & 145 \\
\hline Total & 145 & 145 \\
\hline
\end{tabular}




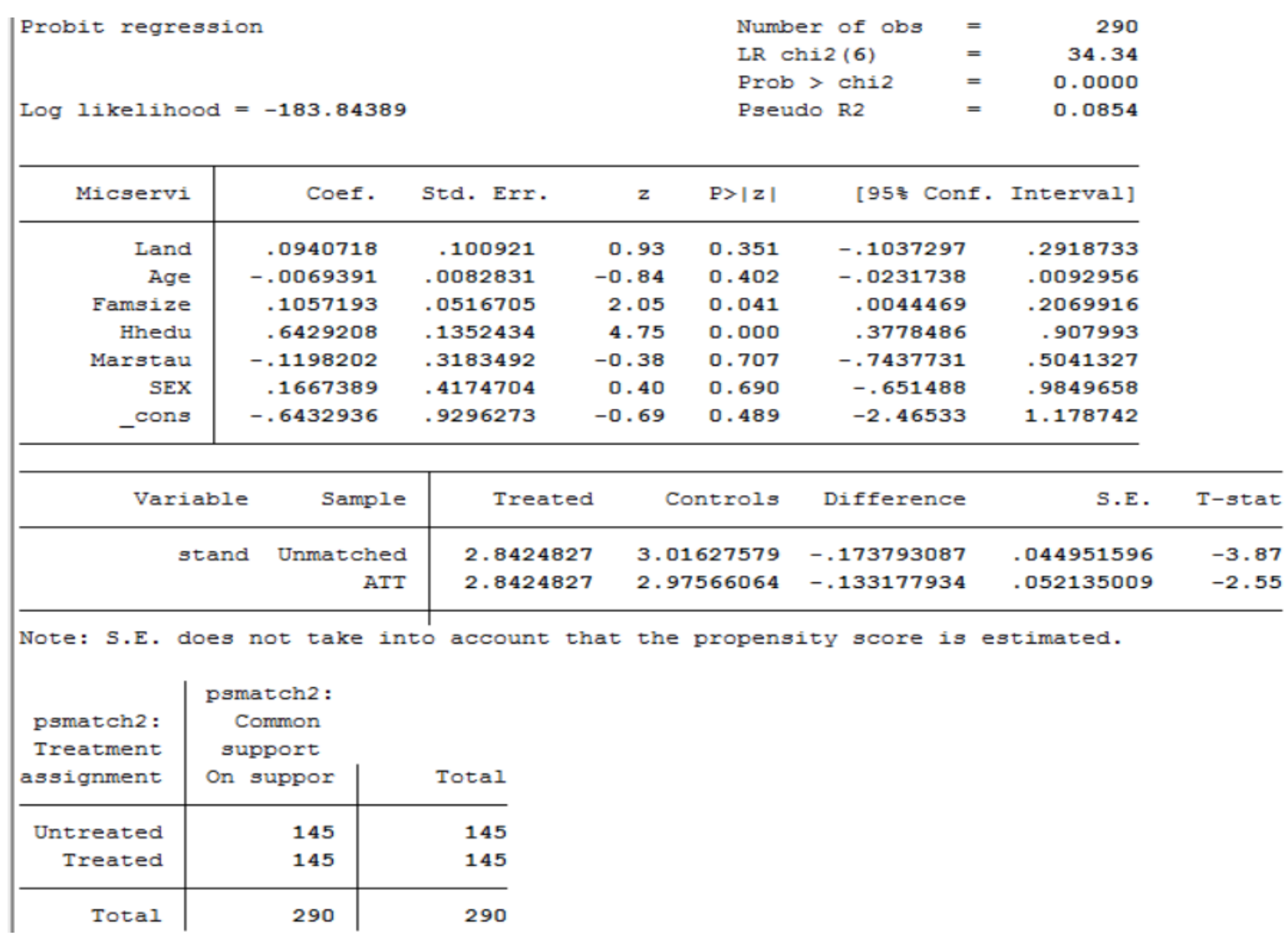

Appendix 2: kernel Density Plot

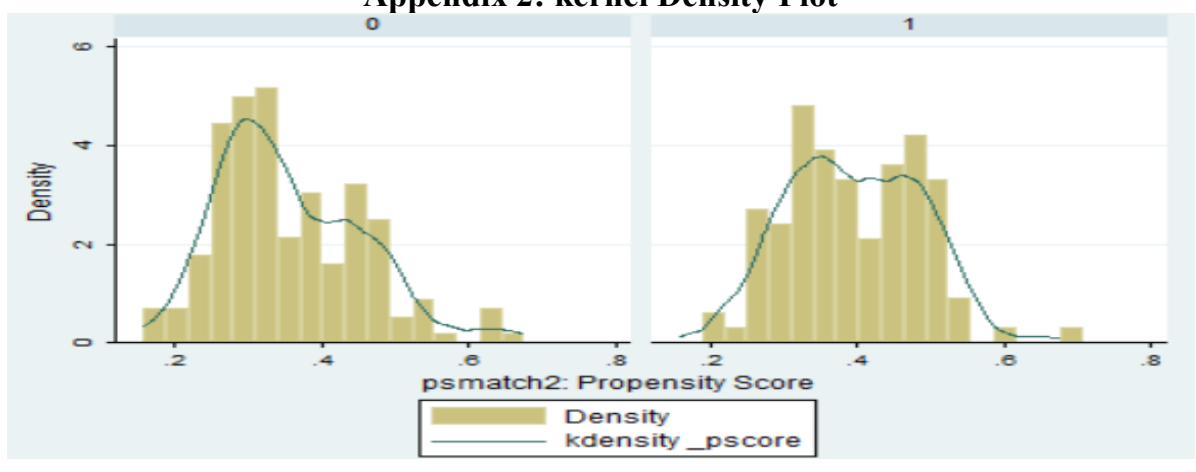

Appenndix 3: PS Test Result

\begin{tabular}{|c|c|c|c|c|c|c|}
\hline \multirow[b]{2}{*}{ Variable } & \multicolumn{2}{|c|}{ Mean } & \multirow[b]{2}{*}{ *bias } & \multicolumn{2}{|c|}{ t-test } & \multirow{2}{*}{$\begin{array}{l}\mathrm{V}(\mathrm{T}) \\
\mathrm{V}(\mathrm{C})\end{array}$} \\
\hline & Treated & Control & & t & $p>|\tau|$ & \\
\hline Land & 1.4838 & 1.4626 & 2.6 & 0.19 & 0.850 & 1.18 \\
\hline Age & 44.472 & 44.593 & -1.2 & -0.09 & 0.927 & 1.31 \\
\hline Famsize & 5.8981 & 5.9559 & -3.6 & -0.28 & 0.783 & 1.02 \\
\hline Hhedu & .58333 & .54359 & 6.5 & 0.49 & 0.622 & 0.94 \\
\hline Marstau & 2.0185 & 2.0184 & 0.1 & 0.01 & 0.996 & 0.79 \\
\hline SEX & .97222 & .97195 & 0.1 & 0.01 & 0.990 & . \\
\hline
\end{tabular}

* if variance ratio outside $[0.68 ; 1.46]$

\begin{tabular}{lccccccc}
\hline Ps R2 & LR chi2 & p>chi2 & MeanBias & MedBias & B & R & svar \\
\hline 0.001 & 0.34 & 0.999 & 2.4 & 1.9 & 8.0 & 0.83 & 0
\end{tabular}

* if $B>25 \%, R$ outside $[0.5 ; 2]$ 


\section{Appendix 4: Senstative (MH) test Result}

\begin{tabular}{|c|c|c|c|c|}
\hline \multicolumn{2}{|c|}{ Mante1-Maenaze1 (1959) } & \multirow{2}{*}{$\begin{array}{l}\text { bounds } \\
\text { e_mb- }\end{array}$} & \multirow{2}{*}{$\begin{array}{c}\text { for variable } \\
\text { P_mbe }\end{array}$} & \multirow{2}{*}{$\begin{array}{l}\overline{-}^{n} \\
\text { P_mh- }\end{array}$} \\
\hline Gamma & Q_mh* & & & \\
\hline 1 & .898944 & .898944 & .004341 & .004341 \\
\hline 1.05 & 1.01389 & .786831 & .02531 & .00056 \\
\hline 1.1 & 1.12281 & .679158 & .430759 & .01519 \\
\hline 1.15 & 1.22736 & .576557 & .402843 & .00009 \\
\hline 1.2 & 1.32793 & .478546 & .400921 & .00002 \\
\hline 1.25 & 1.42487 & .384705 & .277098 & .000228 \\
\hline 1.3 & 1.51846 & .294671 & .064449 & .004123 \\
\hline 1.35 & 1.60898 & .208125 & .05381 & .007566 \\
\hline 1.4 & 0.99667 & .124786 & .04488 & .000347 \\
\hline 1.45 & 0.98171 & .044404 & .037398 & .002291 \\
\hline 1.5 & .864320 & .033242 & .031139 & .000259 \\
\hline
\end{tabular}

Gamma : odds of differential asgignment due to unobserved factors

Q_mht : Mantel-Haenszel statistic (asgumption: overestimation of treatment effect)

Q_mh- : Mantel-Haenszel statistic (asgumption: underestimation of treatment effect)

P_mht : significance level (assumption: overestimation of treatment effect)

p_mh- : significance level (assumption: underestimation of treatment effect) 